\title{
PROSPECT POSSIBILITIES OF REMOTE WORK FOR INVOLVEMENT OF LATVIAN DIASPORA'S IN ECONOMY AND BUSINESSES OF LATVIA
}

\author{
Maira Leščevica, Ieva Kreituze \\ Vidzeme University of Applied Sciences, Latvia \\ Maira.lescevica@va.lv
}

\begin{abstract}
During the last decade a huge number of Latvian citizens have left the country and live abroad, which complicates to a certain extent the chance of easily returning and settling down in Latvia. At the same time, the Latvian entrepreneurs are ultimately demonstrating their desperate need for all kind of workers. Especially it could be seen in sectors like medicine, retail, heavy and light industry. Rapidly growing Diaspora allows to acknowledge that there is a big potential of labour force flowing away from the country, sometimes staying without any work positions for quite a long time. The aim of this article is to find evidence that Latvian Diaspora could be involved in the Latvian economy and business by using a new attitude and approach, which should be supported by teleworking. During research the main methods used were content analysis of strategic and planning documents as well as analysis of the best practices in the world and Latvia, with the aim of establishing a model of remote work development and finding out proposals for a better participation of employees, employers and territory representatives - local governments and state institutions. This article is a part of and supported by the State Research Project EKOSOC-LV, part 5.2.2. The authors express their gratitude to the Institute of Social, Economic and Humanities research of Vidzeme University of Applied Sciences.
\end{abstract}

Key words: Latvian diaspora, flexable working, remote work, entrepreneurship, national economy.

\section{Introduction}

One of the main reasons for establishing European Union (EU) was free mobility of labour.

The labour movement from Latvia started as simple curiosity after joining the EU to examine and try out living and working conditions abroad.

During the last decade many people from Latvia have moved to other EU countries or to other parts of the world trying to find economic benefits and more comfortable living conditions. Although there are many other reasons for migration, in this article authors will be looking only at the economic or wellbeing reasons.

The global circulation of high-skill and low-skill labour from poor economies to rich ones and back is opening new possibilities for economic development. The changes are most noticeable in the behaviour of the most skilled workers (Kuznetsov, 2006).

There are predictions by media experts that in the long term - by 2030 - there could be 120 thousand vacancies, which will demand imported labour. Normal target would be to try to fill these vacancies with people from Latvia, but not emigrants from other countries.

However, previous research has proved that emigration in the long run will threaten the development prospects of Latvian economy, sustainability of social and demographic systems (Buholcs, Goldmanis, \& Hazans, 2016).

It is possible to compensate this negative effect partially by involving Latvian Diaspora in the development of Latvian economy - promoting and supporting the return of emigrants and using their knowledge obtained to start the entrepreneurship, boost economy, culture, education and other important fields (Buholcs, Goldmanis, \& Hazans, 2016).

The aim of this article is to find out if the Latvian Diaspora can be involved in the Latvian economy and business by applying new attitude and approach which is supported by remote working.

During research the main methods used were (1) content analysis of strategic and planning documents to identify the support activities for remigration or involvement, (2) elaboration of the remote work development model and (3) analysis of the best practices in the world and Latvia to find out proposals for better participation of employees, employers and territory representatives - local governments and state institutions.

\section{Materials and Methods}

Diaspora representatives are those people who are promoting Latvia in the world, excellent researchers, entrepreneurs and also ordinary people. They and their children are investors in the long-term development of Latvia (Kḷava, Līcīte, \& Motivāne, 2009).

The Ministry of Foreign Affairs acknowledges that there are more than 400000 Latvian Diaspora representatives living, studying and working outside Latvia in different home countries. Latvian Diaspora includes nationals who have left the territory of Latvia during several emigration waves since the end of the $19^{\text {th }}$ century, including the latest emigrants who still keep in touch with Latvia. The Ministry of Foreign Affairs also realizes that the biggest Latvian communities are in the UK, the USA, Canada, Ireland, Sweden, Australia, Russia, Brazil, Germany, Belgium, Israel, Norway, Spain and other countries in the world. 
Latvian Diaspora is large and includes a great potential for cooperation and representation, as well as the development of Latvian society and state interests.

Diaspora members who want to remain associates and develop cooperation with the country of origin are of value to the entire Latvian society. Their knowledge, capabilities and network of contacts abroad and in Latvia can make a significant contribution to the Latvian transnational community. The Diaspora is a resource, and by strengthening the cooperation mechanisms with the Diaspora it is possible to promote the development of Latvia internally and externally (Ministry of External Affairs, 2015).

In literature the most commonly used term is "Latvian emigrants". The second most often used term for the target group is "diaspora". The Webster Dictionary defines diaspora as "a group of people living outside the area where they lived for a long time or where their ancestors lived" (Buholcs, Goldmanis, \& Hazans, 2016).

In Latvia, with "diaspora", we often refer to the Latvian exile community that emerged in the Western countries after the Second World War. According to the classification of Arjun Appadurai, this community was considered a "diaspora of terror", as it arose in dramatic and precarious conditions. (Appadurai, 1996).

However, after the demise of the USSR, Latvian society encountered other migratory tendencies, in which political motives were replaced by economic ones. With the restoration of Latvia's independence, the exile "terror victims' Diaspora" lost its legitimate basis, but the young emigrants became familiar with the form of solidarity, which Appadurai calls "Diaspora of hope" (Diaspora of hope), a Diaspora that consists of people who seek work and better socioeconomic conditions. As a result, relations between residents of Latvia living abroad and their country of origin have changed or broken up. It is even harder to find a term describing people who have returned to Latvia. Instead, it would be more appropriate to use the word "remigrants" and "immigration" (Buholcs, Goldmanis, \& Hazans, 2016).

Innovative returns are returning emigrants who are ready to use the accumulated assets and knowledge to start a new business or implement other new ideas (Cerase, 1974).

Of course the management of every country who values its own labour force should put effort into innovative returns, where remigrants are ready to use the accumulated assets and knowledge to start new businesses or implement some other new ideas.

Worldwide research on diaspora politics over the period of $1990-2010$ was based on three types of approaches for each year: (1) the use of diaspora resources; (2) value approach, perceiving members of the diaspora as the value of a national state; (3) management approach, in line with global standards. These approaches are complementary and allow broad cooperation with the Diaspora. (Ministry of External Affairs, 2015).

In today's fast-changing environment, with the advent of technology and science, new needs, desires and opportunities arise. Various technological solutions, forms of work, and an unlimited range of resources are available for business development and employee efficiency improvement. Internet accessibility and ICT innovations make it possible to work from anywhere, at any time. As a result, new forms of work are emerging, such as remote work that allows you to work from home or other out-of-office locations and remotely attract professional staff from other cities and countries.

The term "remote work" [in Latvian: telework, teleworking, e-work, mobile work, intellectual work, wise work, etc. In English: 'telework', 'telecommuting', 'smart work', 'remote work', 'distributed work'] is defined differently, but the meaning remains unchanged. The most important things that coincide in all definitions are: work using information technology and work outside the

Table 1

\section{Remote work definitions overview}

\begin{tabular}{|c|l|}
\hline Information origin & \multicolumn{1}{c|}{ Definition } \\
\hline European Commision & $\begin{array}{l}\text { Remote work - the form of organization and / or performance of a work, whereby an employee } \\
\text { can carry out work that could also be carried out at the employer's premises regularly out of } \\
\text { these premises through the use of information technology (European social partners, 2006) }\end{array}$ \\
\hline $\begin{array}{c}\text { Latvian Sustainable } \\
\text { development strategy } \\
2030\end{array}$ & $\begin{array}{l}\text { Remote work - the employment relationship in which the employee performs his duties } \\
\text { without being physically present at the workplace, but using information and communication } \\
\text { technologies }\end{array}$ \\
\hline $\begin{array}{c}\text { Academic terms } \\
\text { databases }\end{array}$ & $\begin{array}{l}\text { Telework, fareway work - Replacing regular work with work at home or at another remote } \\
\text { institution, transmitting data and documents to the central authority by electronic means }\end{array}$ \\
\hline Legal Acts of Latvia & $\begin{array}{l}\text { Teleprocesses - remote actions, processes or procedures that are not taking place directly from } \\
\text { participants in the process (telework, telemedicine, telemedicine) }\end{array}$ \\
\hline
\end{tabular}

Source: created by authors'. 
employer's premises. The definition of the European Commission further emphasizes that the distance work is carried out on the basis of an employment contract / relationship, which is not mentioned in Latvian terms. Latvian legislation does not contain any specific requirements for the employer and organization of a remote job that could explain this fact (Table 1).

There is more and more talk about remote job opportunities in Latvia, but so far this is an incompletely used model of work. Research done in Latvia confirms that most employees would like to work remotely, but knowledge of this type of work and the offer from companies are very small.

In Vidzeme region there is a low population density and that poses a threat to already lowering economic activity. So the question is: how to attract new, talented employees and future professionals. On the one hand, Vidzeme region has the highest proportion of creative class outside Riga region and a high proportion of people with higher education in development centers, which would ensure a widespread employment of the population. On the other hand, the region lacks jobs in the knowledge economy and professional staff. The problem has been identified in the analysis of Vidzeme Planning Region during the last years. This suggests that most young professionals go to work and live outside Vidzeme region and leave their family and home behind. Remote work is one of the ways of attracting highly qualified specialists and marketing to the region.

The topicality and importance of the issue is determined by the decline in population and the lack of professional labor force, which necessitates the search for new solutions for the development of the region and the preservation of rural population. Latvia is a polycentric country with one big city - Riga, - which causes people to leave the countryside and regions.

With the development of modern technologies and Internet access, there are great opportunities for people to work remotely - from home or remote work centers in sparsely populated areas. This will improve the level of employee satisfaction, save time on and off work, and bring a number of economic and social benefits to the company and territory. As a result, regional disparities are reduced and the share of the service sector in the national economy is increasing.

Remote work became popular in the 1970s, when the oil crisis in the world raised concerns about petrol consumption; a long road to work that caused congestions in major metropolitan areas was measured. Remote working opportunities have contributed to the technological advancement; employers have sought to reduce property costs and wanted to reduce workload. (Reilly, Sirgy, \& Gorman, 2012).

On 16 June 2002, the European Commission drafted a framework agreement on remote work and defined it as "a form of organizing and / or enforcement of a job, which an employee could perform at the employer's premises or on a regular basis outside the premises using information technology" (European social partners, 2006).

Regular remote work reduces carbon emissions and has a positive environmental impact. Remote work is seen as a new form of work organization that provides flexibility and security, increases the quality of work, and increases the opportunities for people with special needs to enter the labor market. One of the prerequisites of the European Commission is that remote work is a voluntary choice both by the employer and the employee. Work remotely can be done periodically or independently outside the employer's premises, for example, in a person's home, remote work center or other remote institutions. An essential prerequisite is that the time spent working remotely is to be recorded (European social partners, 2006).

The EU Framework Agreement does not apply to self-employed teleworkers and to occasional teleworkers, for example, if an employee is hired and then "takes work home", but remote work is not included in the employment contract (Akule, 2010).

There are three main types of remote work: working from home, mobile work and remote work in centers (European social partners, 2006).

The experience of European countries shows that nowadays more distant work centers, telecentres or SMART work centers are being built in order to improve economic activity in the more distant regions.

If it was possible to work remotely, $63 \%$ of public administration employees (poll, $n=1244$ ) and $81 \%$ of the population of Latvia (poll, $n=1335$ ) would use it (Project "Smart Work Centers in Non-Metropolitan Areas", 2013).

For example, the Estonian vision for development of 2030 states that "the work will be mainly carried out from home, while office space will be used to communicate with colleagues when discussing work problems and for information exchange" (Estonian Environmental Strategy, 2030).

Figure 1 shows possible professions which can be suitable for remote work.

There are several good practise examples in the world and in Latvia observed during the research.

- http://www.africandiasporanetwork.org/ Founded in 2001, this network focuses on developing knowledge and entrepreneurial connections between the local South African firms and well-connected individuals in the United Kingdom (Kuznetsov, 2006).

- The Indian high-tech diaspora in Silicon Valley and other technology centres in 


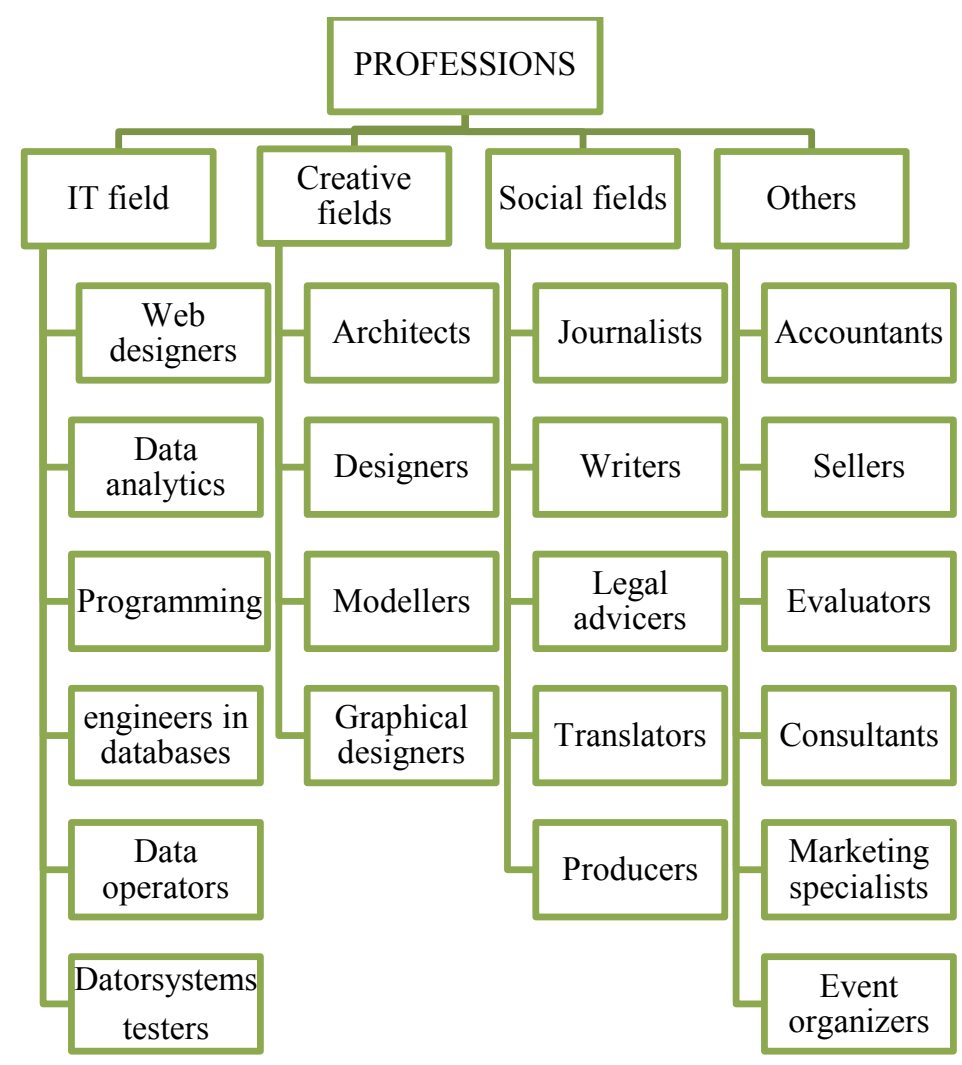

Source: created by authors'.

Figure 1. Potential professions in whichremote work can be applied.

the United States have become organized, forming a transnational community that brings experience, connections, capital, and deals to India (Kuznetsov, 2006).

- The World Latvian Economic and Innovation Forum, organized by PBLA since July 2013, which brought together more than 350 entrepreneurs, researchers, financiers and other professionals from 21 countries, organized by the LTRK and the MFA, was of particular importance in the "Global Latvian" activities program. It helped to stimulate the cooperation of Latvian entrepreneurs and professionals by encouraging engagement and investment in the Latvian economy. In order to achieve good results, such activities should be carried out methodically and regularly, choosing the areas of the relevant cooperation. (Ministry of External Affairs, 2015).

Expatriates do not need to be investors or make financial contributions to make an impact on their home countries. They can serve also as "bridges" by providing access to markets, sources of investment, and expertise. Influential members of diaspora can shape public debate, articulate reform plans, and help implement reforms and new projects. Policy expertise and managerial and marketing knowledge are the most significant resources of Diaspora network (Kuznetsov, 2006).

Here it should be noted that during a recent survey the Ministry of Education and Science has discovered that currently about $40 \%$ of foreign students in Latvia own some land or housing, about $4 \%$ own a company or its parts in Latvia, the same proportion have maintained employment relationships in Latvia, and another $10 \%$ have taken out a mortgage. Similarly, bachelor students abroad often express their intention to establish a company in Latvia in the future, to create or help to establish business cooperation with Latvian partners. In general, about one third of Latvian nationals studying abroad want to enter the Latvian economy by acquiring real estate or engaging in entrepreneurship.

One of the goals of the Remediation Support Action Plan is to promote the creation of jobs, thus encourging the returning immigrants who are jobseekers. According to the data collected by the researcher Mikhail Hazan, only $20 \%$ of those who have left are planning to return to Latvia, taking into account that the longer the time spent in absentia, the less the desire to return.

The "Global Latvian" unified communication platform can offer tools for using existing databases 


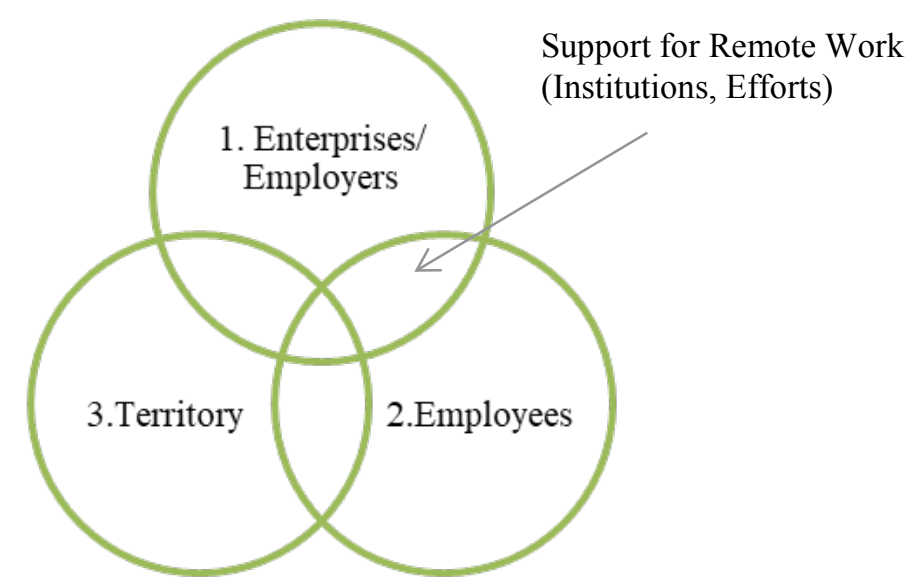

Source: created by authors'.

Figure 2. Model of remote work development and support.

and communicating returning experiences to the community (Ministry of External Affairs, 2015).

All target groups, namely, companies, employees and territory (Figure 2) can participate in the implementation and development of remote work. In order for this cooperation to be effective, there are proposals elaborated to promote remote work deployment and development.

\section{PROPOSALS FOR ENTERPRISES TO PROMOTE DEPLOYMENT AND DEVELOPMENT:}

- Companies that successfully use remote job opportunities or want to start it can be merged into a Remote Work Association.

- Businesses must be aware of all the challenges, benefits and related information of remote work.

- The company must not only provide adequate material resources (transport and communication infrastructure, business support and training), but also social capital, business culture and an appropriate environment that allows adaptation to and benefit from change.

- Entrepreneurs need to be prepared to cooperate with education and research institutions in order to gain higher added value (especially in rural areas).

- Networking and collective learning that fosters innovation and competitiveness of enterprises, not only at the regional, but also national and international levels, should be encouraged. For example, by organizing business forums, engaging in associations, etc.

- Promote the development of ICT in enterprises.

- Support changes in the organization of work, for example, by allowing employees to work flexibly.
- Provide informational support to employees about remote work opportunities.

\section{PROPOSALSFOR POTENTIALLYEMPLOYED} EMPLOYEES:

- Employees must be aware of all the challenges, benefits and related information of remote work.

- Keep up with and learn about the latest developments in the ICT industry, such as lifelong learning programs, universities or courses.

- The ability for people with disabilities to work well and integrate in society.

- Active use of e-services.

- Support mobility activities and take advantage of remote job opportunities

- Engage in communities and organizations through network access.

- Take the opportunity to work in an international company and stay in Latvia.

- Build mutual trust with the job manager.

- Try some type of remote job.

3. PROPOSALS FOR THE TERRITORY (FOR THE VIDZEME AREA) TO PROMOTE OUTDOOR WORK:

- Improve the image and prestige of the site in order to attract professional workforce, distance workers and businesses.

- Improve the quality of living.

- Municipalities have a more favorable attitude towards the population.

- Provide leisure opportunities for the public.

- Develop the school, kindergarten and internet infrastructure.

- Facilitate access to real estate.

- Ensure convenient traffic. 
- Develop a place for marketing and branding (service sector, enhancement of visual attractiveness, promotion of activities, openness to competent young people).

- Provide jobs in the regions of the knowledge economy.

- Support the creation of remote work centers.

- Facilitate informing students about ICT opportunities in the field of education and develop measures to ensure that practical skills are acquired in the latest technologies.

- Stimulate the development of business types whose products have a high added value.

- Provide an active platform for communication and innovation.

- Invest in the area.

- Facilitate co-operation in establishing a remote cluster or association.

- Provide informational support.

4. PROPOSALS FOR DEVELOPED LABOR SUPPORT INSTITUTIONS (FOR REMOTE WORK PROVIDERS' ASSOCIATION):

- Provide informational support and promote remote job opportunities.

- Support the creation of remote work centers.

- Implement a unified model of remote work in Latvia.

- Promote good examples in Latvia and abroad.

- Facilitate the provision of information to students about ICT opportunities, develop measures to ensure the acquisition of practical skills in the latest technologies (ICT career days, Olympiads in Informatics, summer camps, interest groups in social networks).

- To promote citizens' e-skills and Internet access.

- Harmonize labor legislation with the peculiarities of remote work.

- Ensure the social guarantees of the remote employee and the protection of health and safety of work (including working in foreign companies).

- Promote financial support at an early stage in the implementation of the distance work.

- Facilitate tax reductions for employers employing remote workers.

- Promote the integration of distance work into sectoral policies.

- Use the possibilities of EU funds.

- Develop website and other informative materials.

The successful development and distribution of remote work requires the harmonization of labor legislation with the features of remote work. It is important to provide socially guaranteed workers and workers with a high level of protection, occupational safety and health protection (including working in foreign companies). To achieve this, there is a need for a policy of integrating the remote work system into national politics, followed by the attraction and exploitation of the EU background.

\section{Conclusions}

1. During last decade many people from Latvia have moved to other EU countries or to other parts of the world trying to find economic benefits and more comfortable living conditions. By the end of 2030 there will be 120 thousand vacancies, which may lead to labour import.

2. There are at least two ways of eliminating imported labour - the return of emigrants or involvement of Diaspora's representatives in the remote work in Latvia.

3. The Ministry of Foreign Affairs acknowledges that there are more than 400000 Latvian Diaspora representatives living, studying and working outside Latvia in different home countries.

4. Diaspora members who want to remain associates and develop cooperation with the country of origin are of value to the entire Latvian society. Their knowledge, skills and network of contacts abroad and in Latvia can make a significant contribution to the Latvian transnational community.

5. With the development of modern technologies and Internet access, there are great opportunities for people to work remotely - from home or remote work centers in sparsely populated areas. Remote work is seen as a new form of work organization that provides flexibility and security, increases the quality of work, and increases the opportunities for people with special needs to enter the labor market. There are three main types of remote work: working from home, mobile work and remote work centers.

6. If it was possible to work remotely, $63 \%$ of public administration employees and $81 \%$ of the population of Latvia would use it.

7. In general, about one third of Latvian nationals studying abroad want to enter the Latvian economy by acquiring real estate or engaging in entrepreneurship.

8. The "Global Latvian" unified communication platform can offer tools for using existing databases and communicating the experience of returning to the community.

9. All target groups, namely, companies, employees and territory, can participate in the implementation and development of remote work. In order for this cooperation to be effective, there are proposals elaborated to promote remote work deployment and development. 


\section{Acknowledgement}

This article is part of and supported by the state supported research project EKOSOC-LV, part
5.2.2. Gratitude to Institute of Social, Economic and Humanities research of Vidzeme University of Applied Sciences.

\section{References}

1. Akule, D. (2010). Rokasgrāmata par Eiropas sociālo partneru darba programmas 2009.-2010. gadam un Eiropas sociālo partneru pamatnolīgumu īstenošanu un ieviešanu praksē (Handbook of European social partner's work programme 2009-2010 and European social partner's basic agreement realization and implementation). Rīga: Veiters korporācija, 135. lpp. (in Latvian).

2. Appadurai, A. (1996). Modernity At Large: Cultural Dimensions of Globalization. Minneapolis. University of Minnesota Press, 355 pp.

3. Buholcs, J., Goldmanis, M., \& Hazans, M. (2016). Emigrant Communities of Latvia: Diaspora of Hope, edited by Inta Mieriņa. Publisher Latvijas Universitātes aǵentūra "Latvijas Univeristātes Filozofijas un sociologijas institūts", $240 \mathrm{pp}$.

4. Cerase, F. (1974). Expectations and reality: a case study of return migration from the United States to Southern Italy. International Migration Review, 8(2), pp. 245-262.

5. Estonian Ministry of Environment (2007). Estonian Environmental Strategy 2030, Retrieved March 13, 2018, from: http://www.envir.ee/sites/default/files/keskkonnastrateegia_inglisek.pdf.

6. European social partners (2006). Implementation of the European framework agreement on telework, report by the European social partners, $36 \mathrm{pp}$.

7. Kḷava, G., Līcīte, V., \& Motivāne, K. (2009). Language usage in Diaspora: practises of other countries and evaluation of Latvian legal capacity, project experts D. Dalbiņa, I. Druviete. Publisher: Latviešu valodas aǵentūra, $99 \mathrm{pp}$.

8. Kuznetsov, Y. (2006). Diaspora networks and the international migration of skills: how countries can draw on their talent abroad / edited by Yevgeny Kuznetsov. Publisher: Washington, DC: World Bank, 237 pp.

9. Ministry of External Affairs (2015). Action plan for cooperation with the Latvian Diasporas 2015-2017, place of publication: Ministry of External Affairs, $27 \mathrm{pp}$.

10. Project "Smart Work Centers in Non-Metropolitan Areas" (2013). Iedzīvotāju viedoklis par teledarba attīstības iespējām Latvijāa (Citizens opinion of teleworking development possibilities in Latvia). Survey results, 34 pp. (in Latvian).

11. Reilly, N.P., Sirgy, M.J., \& Gorman, C.A. (2012). Work and Quality of Life Ethical Practices in Organizations. Springer Science, Business Media B.V., pp. 256-264. 